\title{
Insights into international branch campuses: Mapping trends through a systematic review
}

\author{
María Escriva-Beltran $^{\mathrm{a}, *}$, Javier Muñoz-de-Prat ${ }^{\mathrm{a}, \mathrm{b}}$, Cristina Villó ${ }^{\mathrm{b}}$ \\ ${ }^{\text {a } U n i v e r s i d a d ~ C a t o ́ l i c a ~ d e ~ V a l e n c i a ~(S a n ~ V i c e n t e ~ M a ́ r t i r) ~ F a c u l t a d ~ d e ~ C C ~ E c o n o ́ m i c a s ~ y ~ E m p r e s a r i a l e s, ~ S p a i n ~}$ \\ ${ }^{\mathrm{b}}$ Escuela de Doctorado Universidad Católica de Valencia (San Vicente Mártir), Spain
}

\section{A R T I C L E I N F O}

\section{Keywords:}

International branch campus

Offshore campuses

Higher education

Internationalization

Cross-border education

\begin{abstract}
A B S T R A C T
This study analyzes international branch campus (IBC) literature trends from 1960 to 2017 through a systematic review of the different research approaches, views, and positions to map the global scientific production. Over the last two decades, universities worldwide have opened branch campuses abroad, reaching a peak of 249 across thirty-three countries in January 2017. In fact, international studies and surveys have identified a $26 \%$ increase over the last five years as well as a concentration of the industry. Since 2017, the emergent field of IBC has experienced a geometric growth regarding the number of academic publications on this topic. The results of the review indicate an important amount of literature on IBC related to some of the topics studied-managerial and academic staff issues and educational hubs_-and a lack of research on a wide range of areas.
\end{abstract}

\section{Introduction}

Globalization, as one of the most powerful worldwide business drivers, has turned higher education (HE) into "a global business engaging in marketing strategies to sell their knowledge-based products, attract foreign students, and establish international branches" (Spring, 2009, p.100).

The Observatory on Borderless Higher Education's (OBHE) latest definition of an international branch campus (IBC) is that of "an entity that is owned, at least in part, by a foreign education provider; operated in the name of the foreign education provider; and provides an entire academic program, substantially on site, leading to a degree awarded by the foreign education provider" (Garrett, 2017, p. 7). However, the heterogeneity in IBC models makes the definition of IBC a moving target since, through its evolution, the term has come to include new and different offshore activities due to a changing legal background, competitive environments affecting ownership, academic governance, and financial and legal structures. Therefore, any given definition will arbitrarily include some IBCs and exclude others (Altbach, 2015; Becker, 2009; Borgos, 2016; Healey, 2014, 2015a; Healey \& Michael, 2015; Kinser \& Lane, 2015; Lane \& Kinser, 2011a, 2013; Lawton \& Katsomitros, 2012; Wilkins, 2016).

IBC emerged as a popular form of transnational HE (Wilkins \& Balakrishnan, 2012) because IBC is the most tangible and high-profile form of this growing trend. IBC represents the final stage of HE internationalization: establishing a satellite campus in another country (Healey, 2014). However, IBC is also one of the most unexplored and riskiest HE entry modes to international markets (Beecher \& Streitwieser, 2017; Girdzijauskaite \& Radzeviciene, 2014; Healey, 2015b; Wilkins \& Huisman, 2013).

Therefore, this study analyzes IBC literature trends from 1960 to 2017 in order to map the global scientific production on IBC through a systematic review. This systematic review identifies the major types and categories of IBC.

The article is structured as follows: Section 2 portrays IBC's background and evolution. Section 3 presents the research methodology, including the selection process and study of the 173 articles. Section 4 outlines the whole scope of research on this phenomenon over a sixtyyear period, disclosing publication patterns, types of articles and citation structure. Section 5 establishes nine wide-range research areas that enclose the diverse IBC perspectives that scholars follow, so as to map out IBC research. Finally, Section 6 concludes by giving a comprehensive overview of IBCs and providing directions for future research.

\section{Background: Origins, development, and evolution of IBCs}

The roots of branch campuses date back to the beginning of the 19th or even the 18th century, but HE literature usually identifies the Johns Hopkins University campus as the first IBC, established in 1950 in Italy (Becker, 2009); nevertheless, initial developments surged as early as in

\footnotetext{
* Corresponding author.

E-mail address: maria.escriva@ucv.es (M. Escriva-Beltran).
} 


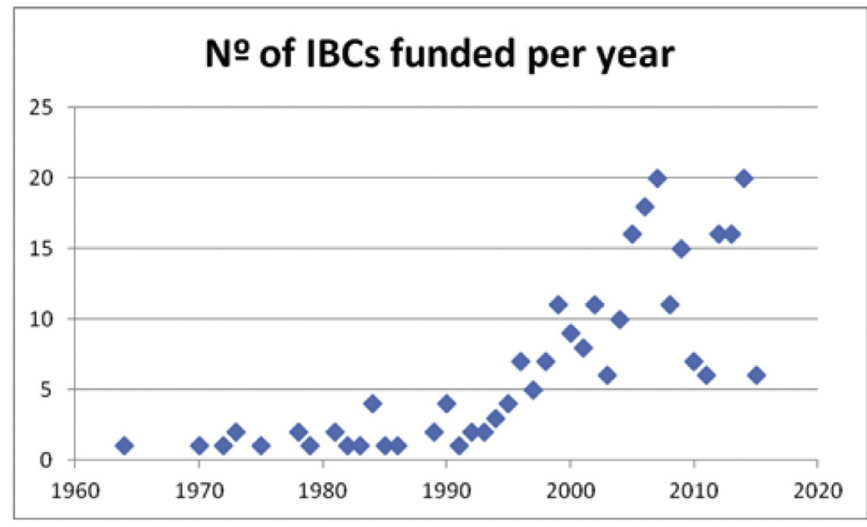

Fig. 1. International branch campus openings per year 1964-2016. Source: OBHE (analysis updated in December 2016), International branch campuses - Trends and developments.

1933, when Florida State University began offering programs in Panama. However, IBCs' further development was slow, since up to the 1970 s only five IBCs had appeared. During the 1980s, IBC development experimented a significant increase (Lane, 2011). In this period, several countries experienced rapid economic growth and developing economies in particular shifted their strategic focus to find ways to align their education system with the workforce training needed in their country (Borgos, 2016).

However, not much more occurred until the late 1990s and 2000s (Knight, 2008; Kosmützky, 2014; Lane \& Kinser, 2011b) as Fig. 1 shows; since the late 1990s, these entities began to proliferate internationally, as many colleges and universities established physically in foreign countries. Advances in technology, infrastructure, and transportation are some of the factors enabling the physical movement of institutions across geopolitical borders at an unprecedented rate (Knight, 2008). Between 2006 and 2011, the number of IBCs grew from 85 to around 200, which represents a $144 \%$ increase during this period and one of the most striking developments in the internationalization of HE (Healey, 2015a; Lawton \& Katsomitros, 2012; Verbik \& Merkley, 2006).

Since 2012, IBCs have undergone a growth and diversification phase, reaching 249 operating IBCs worldwide in January 2017. The founders were universities or colleges from thirty-three countries (home countries) and they are operating in seventy-six importing or host countries, which accounts for a $26 \%$ increase over the last five years. Interestingly, according to the last published data, 22 new IBCs were planning to open, whereas 42 had closed or changed their status during that time. In absolute terms, growth is steady: 66 new IBCs appeared between 2011 and 2015, and 67 between 2006 and 2010 (OBHE, 2016).

The OBHE and the C-BERT reported that the largest countries exporting BCs-home countries-are mostly developed countries located in the West, which represents $73 \%$ of all IBCs worldwide; in addition, the United States represents a third of the total (Table 1).

On the other hand, China ranks first among the top five BC largest

Table 1

Countries exporting BC.

Source: OBHE (updated in January 2017)

\begin{tabular}{lr}
\hline Countries exporting branch campuses & Number of branches \\
\hline United States of America & 77 \\
United Kingdom & 38 \\
France & 28 \\
Russia & 21 \\
Australia & 14 \\
Others & 71
\end{tabular}

Table 2

Top 5 host countries according to the total number of IBC.

Source OBHE (updated in January 2017)

\begin{tabular}{lr}
\hline \multicolumn{1}{c}{ Host countries } & Number of operating IBC \\
\hline China & 32 \\
United Arab Emirates, Dubai & 24 \\
Malaysia & 12 \\
Qatar & 11 \\
Singapore & 11 \\
\hline
\end{tabular}

importers (host countries) and represents 39\% of the world's total number of IBCs. Over the last five years, China has become the largest host country due mainly to the substantial support from the Chinese government, thus surpassing the United Arab Emirates (Table 2).

In absolute terms, IBC has experienced a steady growth between 2011 and 2015, including 66 new IBCs, in contrast with 67 new IBCs established in the previous period, from 2006 to 2010 (Garrett, Kinser, Lane, \& Merola, 2016). This striking growth in the number of offshore campuses has motivated the exploration of previous research on the topic through a systematic review that allows to conceptualize the existing literature.

To conclude this section, the results show a parallelism between Figs. 1 and 2, hence the number of publications related to IBC matches the tendency of IBC physical openings.

\section{Method}

With the objective to understand the IBC expansion, this study presents a systematic review to map and analyze the existing literature on the subject. Regarding the method and data, the general trend is in favor of a qualitative approach with statistical analysis, such as regression analysis and multi-level modelling. Nevertheless, this study follows the standard approach used in Jormanainen and Koveshnikov (2012) and Surdu and Mellahi (2016) to review international business studies.

Taking the OBHE and C-BERT surveys and reports as a starting point, an Internet search was conducted through all publications in the following search engines: Web of Science, The Educational Resources Information Centre (ERIC), and Google Scholar using the following search terms: "international branch campus," "transnational education," "foreign branch campus," and some other terms such as "offshore campuses," "cross-border education," or "borderless education".

Once the bibliographic search was conducted, titles and abstracts were reviewed in order to narrow down the results to only those items directly related to the IBC. Therefore, the final sample results from the filtering process explained above, yielding a final selection of 173 documents closely linked to IBC.

\section{Publication patterns, types of articles, and general citation structure}

As previously mentioned, since 2002, IBCs had been steadily growing, but research began to focus on the topic in 2010 (Figs. 1 and 2). The final 173 documents date mainly from the period 2000-2017. This section shows the grouping of the documents by structure and other criteria.

In general, the results reveal that earlier literature on internationalization in HE tended to be more conceptual and theoretical, full of unclear demarcations of concepts (Kehm \& Teichler, 2007). On the other hand, more recent research has offered insights into isolated thematic islands by reviewing research only on particular themes and geographic areas of transnational and cross-border HE (Kosmützky \& Putty, 2016; Waterval, Frambach, Driessen, \& Scherpbier, 2015). However, this analysis identifies the following five thematic sections: 


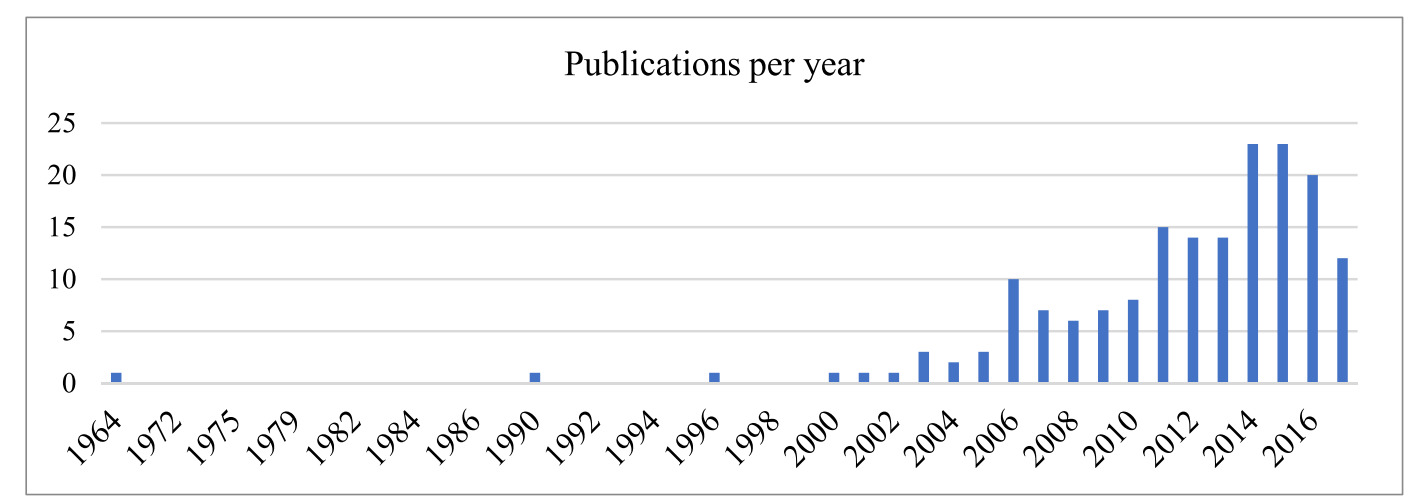

Fig. 2. Number of publications per year 1964-2017.

Table 3

Number of publications per type of document.

\begin{tabular}{lrr}
\hline Type of publications & Number of publications & $\%$ Total \\
\hline Journal articles & 113 & $65.32 \%$ \\
Book section & 16 & $9.25 \%$ \\
Books & 513 & $6.94 \%$ \\
Web pages & 11 & $6.36 \%$ \\
Thesis & 8 & $4.62 \%$ \\
Reports & 7 & $4.05 \%$ \\
Conference paper & 3 & $1.73 \%$ \\
Research paper & 2 & $1.16 \%$ \\
Essay & 1 & $0.58 \%$ \\
Total & 173 & \\
\hline
\end{tabular}

\subsection{By publication year}

Fig. 2 describes publications per year, revealing that the IBC phenomenon has attracted scholars' interest especially over the last five years.

\subsection{By type of document}

The 113 journal articles published account for $65 \%$ of the output from 2000 to 2017; while book sections, books and web pages rank second, third, and fourth respectively $(16,12$, and 11 items respectively). Finally, the group of items comprising theses, reports, conference papers, and essays represent $11 \%$ of the total (Table 3 ).
Table 5

The most prolific researchers.

\begin{tabular}{lr}
\hline \multicolumn{1}{c}{ Researchers } & Number of publications \\
\hline Knight, J. & 18 \\
Wilkins, S. & 16 \\
Lane, J. E. & 12 \\
Healey, N. & 9 \\
Huisman, J. & 8 \\
Altbach, P. G. & 6 \\
\hline
\end{tabular}

\subsection{By journal title}

Despite the wide range of publications dealing with the topic, four journals garner most of the research. Table 4 lists all the journals with more than two IBC publications. 16 journals published $53.5 \%$ of these articles, and JSIE holds $21.95 \%$ of the total publications related to the topic. The list includes specialized journals on international higher education, some of the major international academic journals, academic books, and magazines for professional international educators.

\subsection{By author}

Table 5 shows the most relevant scholars regarding the number of publications they have on IBCs. The remaining of the authors have six publications or fewer.

\subsection{By citations}

Taking into consideration the whole search scope, Table 6 shows the

Table 4

Number of publications per journal title.

\begin{tabular}{|c|c|c|c|}
\hline Title of journals & Namely & Number of publications & $\%$ Total \\
\hline The Journal of Studies on International Education & JSIE & 18 & $21.95 \%$ \\
\hline International Higher Education & IHE & 13 & $15.85 \%$ \\
\hline The Observatory on Borderless Higher Education & OBHE & 7 & $8.54 \%$ \\
\hline Higher Education & HE & 9 & $10.98 \%$ \\
\hline Higher Education Policy & HEP & 4 & $4.88 \%$ \\
\hline New Directions for Higher Education & NDHE & 4 & $4.88 \%$ \\
\hline International Journal of Educational Management & IJEM & 5 & $6.10 \%$ \\
\hline Journal of Higher Education Policy and Management & JHEPM & 3 & $3.66 \%$ \\
\hline Asia Pacific Education Review & APER & 3 & $3.66 \%$ \\
\hline Quality in Higher Education & QHE & 3 & $3.66 \%$ \\
\hline Studies in Higher Education & SRHE & 3 & $3.66 \%$ \\
\hline Journal of Research of International Education & JRIE & 2 & $2.44 \%$ \\
\hline Perspectives: Policy and Practice in Higher Education & PPP & 2 & $2.44 \%$ \\
\hline Studies in Higher Education & SRHE & 2 & $2.44 \%$ \\
\hline The Journal of Continuing Higher Education & JCHE & 2 & $2.44 \%$ \\
\hline Higher Education Quarterly & HEQ & 2 & $2.44 \%$ \\
\hline Total & & 82 & \\
\hline
\end{tabular}


Table 7

Research areas and number of publications related to IBC.

\begin{tabular}{cc}
\hline Research areas to analyze IBC & Number of publications \\
\hline Institutional reasons to establish an IBC & 9 \\
Models of International Branch Campus & 3 \\
Students issues & 9 \\
Academic staff issues & 15 \\
Managerial issues & 26 \\
Educational hubs & 15 \\
Sustainability & 9 \\
Language. English as lingua franca & 6 \\
Parallelism with a subsidiary of a multinational & 10 \\
corporation &
\end{tabular}

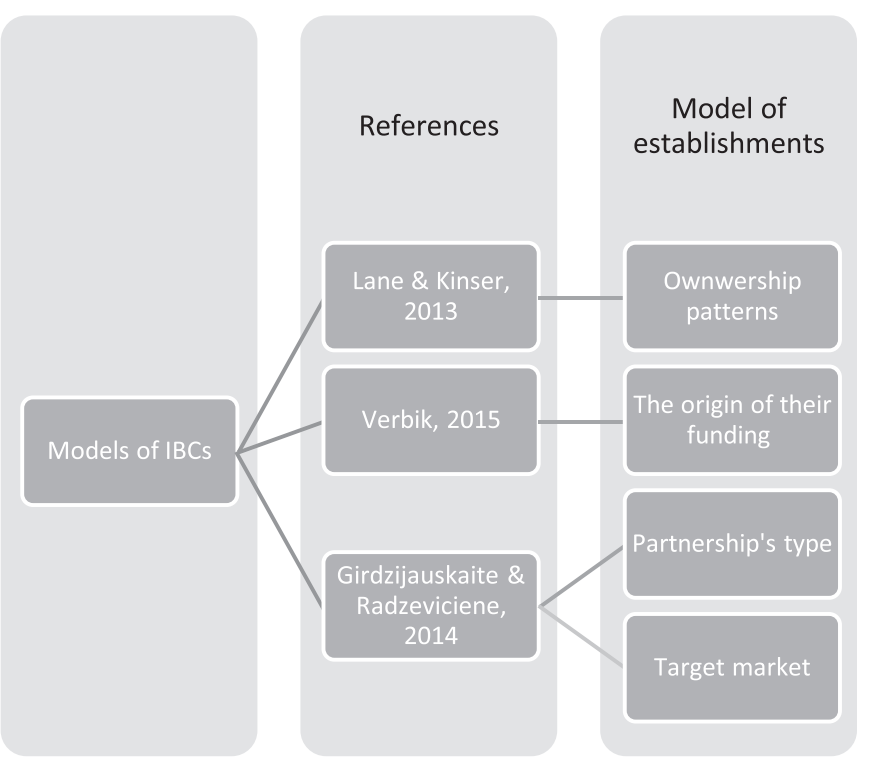

Fig. 3. Models of IBC foundations.

most cited authors, with a threshold of 100 citations per article.

\section{Thematic structure}

Given that scholars are drawing on very diverse perspectives to analyze offshore campuses; a framework of interconnected thematic groups serves to categorize the findings of the systematic review. Table 7 shows the nine areas that include these thematic groups.

\subsection{Institutional reasons to establish an IBC}

The literature renders a wide range of reasons behind the idea of setting up an international campus abroad. First of all, competing for reputation and academic prestige could be the main reason to establish foreign operations through offshore campuses (Mazzarol, Norman Soutar, \& Sim Yaw Seng, 2003; McBurnie \& Ziguras, 2006). However, some critics state that these establishments may be a new form of colonialism (Nguyen, Elliott, Terlouw, \& Pilot, 2009) because, on one the hand, transnational HE often flows from more developed to less developed nations (Naidoo, 2006) and, on the other hand, Anglo Saxon countries-United States, United Kingdom, and Australia-have been the dominant exporting countries (Zhang, Kinser, \& Shi, 2014).

As for the main triggers of IBC internationalization, authors such as Altbach (2007a) and McBurnie and Ziguras (2006) argue that the main variables are politics, ideologies, profit and market-driven policies, and demand for transnational education, that is, the student's desire to engage in educational and social experiences.

Although empirical research is scarce, the most common reason 


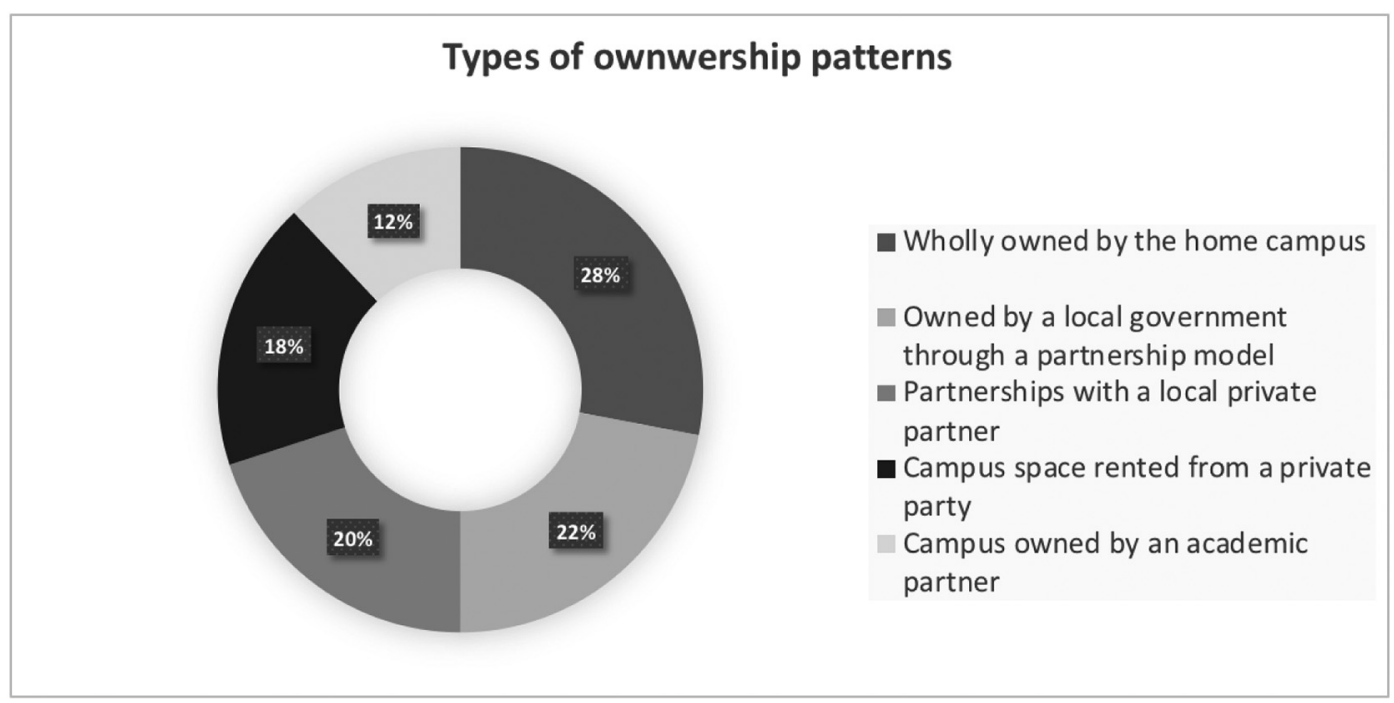

Fig. 4. Types of ownership patters on IBC.

Source: Lane and Kinser (2013)

cited in the literature is financial opportunities. Home universities look for new revenue streams, new sources of additional income as well as the advantages of the monetary incentives that local host governments offer (McBurnie \& Ziguras, 2006; Naidoo, 2006; Verbik \& Merkley, 2006; Wilkins, 2012; Wilkins \& Huisman, 2012). Other reasons refer to global brand recognition for a university seeking prestige and enhanced reputation as an educational quality institution (McBurnie \& Ziguras, 2006; Naidoo, 2006; Harding \& Lammey, 2011), as well as the willingness of home countries to open up a range of student and faculty research and exchange opportunities (Garrett \& Verbik, 2004).

On the other hand, host governments search foreign universities to establish offshore campuses because their countries and national economies benefit in a multitude of ways (Lane \& Kinser, 2011b; Lee, 2015; Wilkins, 2013).

\subsection{Models of IBCs}

Once the decision to open an offshore IBC has been made, HE institutions can choose among a series of models to establish their "physical plant" (Girdzijauskaite \& Radzeviciene, 2014; Lane \& Kinser, 2013; Verbik, 2015). Fig. 3 presents these models.

A survey of 50 BCs conducted by CBERT in 2011 (Lane \& Kinser, 2013) reveals five types of ownership patterns (Fig. 4).

Verbik (2015) provides three different models of IBC depending on the source of funding. The first model involves funding by the institution and is the least common because institutions seek more collaborative approaches. The second model involves external funding from either the host government or private companies. In the third model, a company or a national government provides the facilities.

On the other hand, Shams and Huisman (2012) compare a university to a business firm entering new markets. In the same vein, Girdzijauskaite and Radzeviciene (2014) classify the modes of branch campus into two groups according to the partnership form and the target market. Regarding the partnership form, the authors divide BCs into three groups: (1) a subsidiary with certain operations individually offshored to a foreign country; (2) a joint venture in which a bilateral or multilateral merge of HE institutions takes place; and (3) a universitybusiness venture. Regarding the target market, IBC may involve the following kinds of campuses: (1) education campus, which has undergraduate students as the only target; (2) graduate, post graduate and $\mathrm{PhD}$ students; and (3) students and research campus. Fig. 5 displays the complete map.

\subsection{Students issues}

The motivations behind students' preferences are those of convenience, such as keeping their present job, avoiding the time and cost of international traveling, being able to live with their family, and others such as campus location, entry requirements, tuition fees, comparatively low cost of living, safe country for living, stable government, modern amenities, proximity in culture and religion and freedom from discrimination, quality reputation, or the international recognition of education qualifications (Ahmad \& Buchanan, 2016; Healey, 2015a; Hoyt \& Howell, 2012; Mazzarol et al., 2003; Wilkins \& Balakrishnan, 2013; Wilkins, Balakrishnan, \& Huisman, 2012; Wilkins \& Huisman, 2015).

\subsection{Academic staff issues}

The success of an offshore campus depends, first, on attracting and retaining high quality academic staff (Altbach, 2004). In fact, staffing will continue as the biggest strategic challenge offshore campuses face (Edwards, Crosling, \& Lim, 2014; Hughes, 2011; Mcdonald, 2006; Salt \& Wood, 2014; Shams \& Huisman, 2012, 2014). In addition, some other factors related to academic staff that may be a major influence are the adaptation of the curriculum to local norms and regulations (Shams \& Huisman, 2012, 2016), a good relationship between the home campus and the local educational and political context, and between home and host academic staff (Crosling, 2011; Edwards et al., 2014; Hughes, 2011; Smith, 2009) and, finally, the intercultural competence, which is essential for faculty members to understand a transnational classroom (McBurnie \& Ziguras, 2009; Sia, 2015; Wallace \& Dunn, 2013; Ziguras, 2013).

\subsection{Managerial issues}

Given that most recent IBCs aim at generating revenue, research on this topic focuses on business strategies. Thus, the business literature provides insights that shed light on the tensions resulting from the participation of HE institutions in transnational education (Edwards et al., 2014) and on different approaches relating BCs management to strategic management and international business literature (Table 8).

\subsection{Sustainability}

IBCs' sustainability draws on their ability to adapt different local 


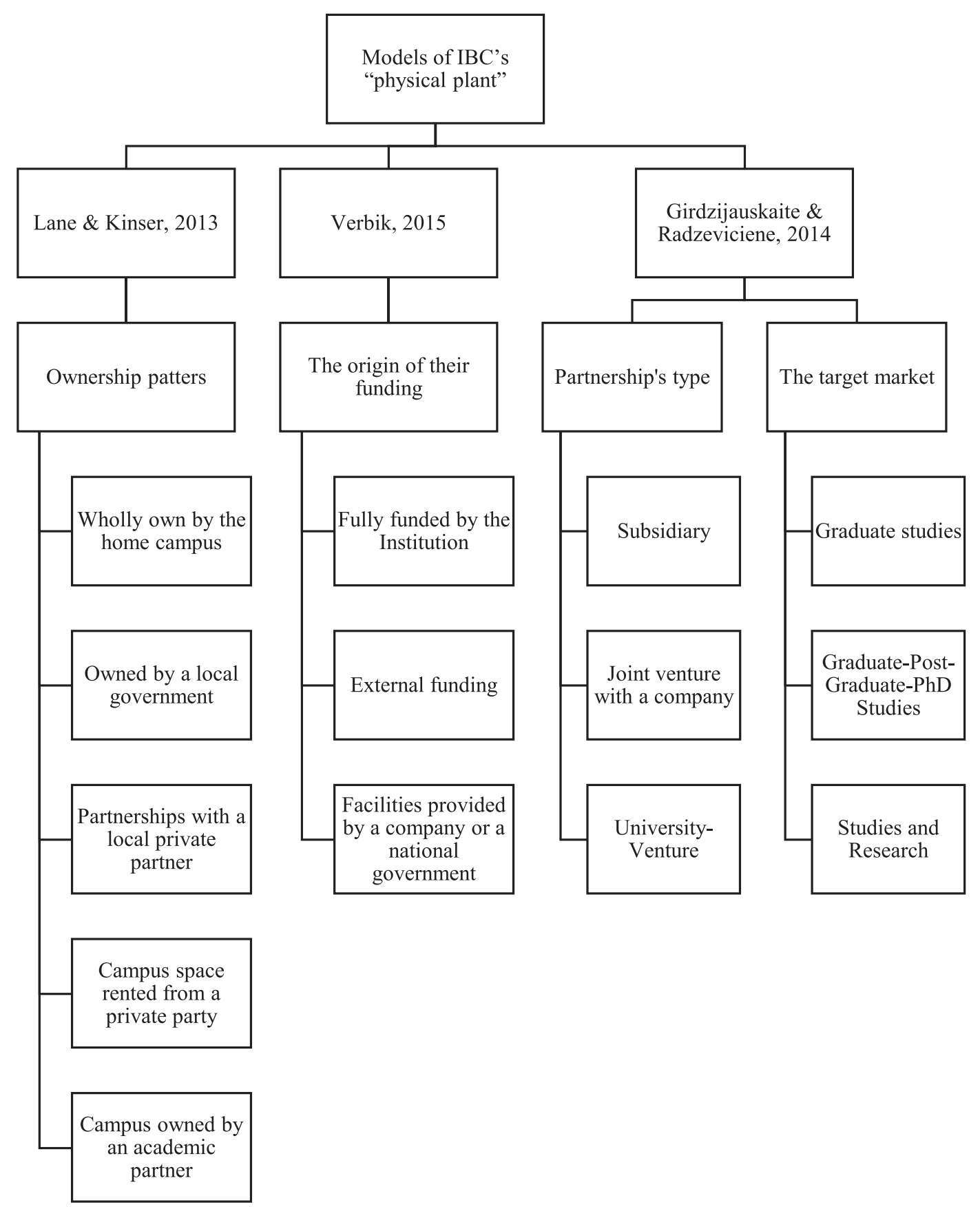

Fig. 5. Models to establish an IBC as "physical plant".

Table 8

Managerial issues criteria: Relating BCs management to strategic management and international business literature.

\begin{tabular}{ll}
\hline Criteria & Reference \\
\hline $\begin{array}{l}\text { Strategic leadership } \\
\text { Corporate risk }\end{array}$ & Healey, 2016; Hughes, 2011; Lane, 2011; Lane and Kinser, 2011a, b; Schuman, 2009 \\
Institutional strategies & Beecher \& Streitwieser, 2017; Healey, 2015b; Lim and Saner, 2011; McBurnie and Pollock, 2000 \\
$\begin{array}{l}\text { Quality assurance } \\
\text { Marketing or branding }\end{array}$ & Widdlehurst and Woodfield, 2007; Phillips, Tracey, and Karra, 2009; Shams \& Huisman, 2012, 2014; Wilkins, 2016 \\
Organizational culture & Wilkins \& Huisman, 2014, 2015 \\
Market entry strategies & Bartell, 2003; Golkowska, 2016; Tierney and Lanford, 2015 \\
Cross-cultural challenges & Girdzijauskaite and Radzeviciene, 2014; Harding \& Lammey, 2011; Jiang, and Carpenter, 2011 \\
Stakeholders & Eldridge and Cranston, 2009; Gopal, 2011; Knight, 2015; Lane, 2013, 2015; Marginson and van der Wende, 2007 \\
\hline
\end{tabular}


environments—social, cultural, and educational-to the respective host country as regards enrolment numbers, sources of revenue, quality of curriculum, academic freedom, availability of faculty, and adaptation to local conditions (Bhuian, 2016; Borgos, 2016; Crombie-Borgos, 2013; Franklin \& Alzouebi, 2014; Knight, 2014b; Kosmützky, 2014; Wilkins, 2017; Wilkins \& Huisman, 2012).

\subsection{Language: English as lingua franca}

The general assumption is that the language of transnational HE programs should be English in order to obtain recognition as legitimate "international" programs (Altbach, 2007b; Wilkins \& Urbanovic, 2014).

English as a science and international HE lingua franca undoubtedly benefits countries such as the United States, the United Kingdom, or Australia, but this status has also benefited institutions in non-English speaking countries such as the Netherlands, a country that is establishing branches overseas with programs delivered in English (Wilkins, 2012). Therefore, the supremacy of English as teaching and research medium creates a clear advantage for the countries that use English on a regular basis.

In addition, students in host countries believe that English fluency skills are essential to be competitive in the labor market, especially among multinational employers. Regardless of this trend, scholars argue that in ten or twenty years' time, languages such as Spanish and Chinese could become alternative languages commonly used in transnational HE (Wilkins, 2012; Wilkins \& Urbanovic, 2014). Nevertheless, all these elements mean that developing countries depend on the major academic superpowers (Altbach, 2015).

\subsection{Parallelism with a subsidiary of a multinational corporation}

Scholars argue that as some universities become more global, they will act as multinational businesses, as they outsource their management and workforce globally. The literature review has shown that nearly all the studies explore the motives behind the multinational university through the lens of the eclectic paradigm. The results explain how IBCs benefit from their competitive advantage and internalization costs in order to offshore HE (Bhanji, 2008; Edwards et al., 2014; Gallagher \& Garrett, 2012; Guimon, 2016; Healey \& Bordogna, 2014; Lane \& Kinser, 2011a; Salt \& Wood, 2014; Shams \& Huisman, 2012; van Rooijen, 2006; Wilkins \& Huisman, 2014).

\subsection{Educational hubs as business hubs}

In general, host economies, particularly in small countries in the Middle East and Southeast Asia-mainly in Hong Kong, Malaysia, Singapore, Qatar, the United Arab Emirates, and Botswana-have established several international HE hubs, offering foreign campuses favorable conditions or incentives such as cash and land grants or tax breaks (Ahmad \& Buchanan, 2016; Knight, 2011, 2013, 2014a, 2014b, 2014c; Knight \& Lee, 2014; Knight \& Morshidi, 2011; Kosmützky, 2014; Lane \& Kinser, 2011b; Lawton \& Katsomitros, 2012; Singh, 2014; Wilkins, 2010; Wilkins \& Huisman, 2015).

Regarding the advantages for a host country or city to serve as an education hub, scholars determine three aspects (Cheng, Cheung, \& Yeun, 2011) that can contribute jointly to the formation of an education industry: economic growth, internationalization of $\mathrm{HE}$ as academic institutions' response to a globalized world and global branding (Altbach \& Knight, 2007), and a means to attract foreign students to study in local tertiary institutions while enhancing the international capacity of these institutions.

\section{Discussion and conclusion}

Research on IBCs is a recent trend and a consequence of the latest initiatives by some HE institutions to establish campuses offshore. A review of the existing literature has allowed to obtain the conceptual map of this topic and to build an integrated and up-to-date description of IBC's theoretical framework through a systematic review. Research on this area can help policymakers and university managers in their decision-making processes.

This review draws on an overarching framework that groups a large and varied number of publications on IBC published over the past sixty years. This framework allows the identification of nine different thematic research areas in which academics have shown interest: institutional reasons to establish an IBC, models of IBC, student issues, academic staff issues, sustainability, English as a lingua franca, parallelism with a subsidiary of a multinational corporation, and educational and business hubs.

The results suggest several current research trends on IBC and identify some different and interesting gaps in the literature related to three theoretical perspectives: international migration flows, universities, and host and home countries. First, the relevance of international flows of skilled migrants between HE institutions lies on their effect on students' behavior and on professors, researchers and university managers' performance. Second, from the university's perspective, the literature suggests that as universities become more global, they will act as multinational corporations. The most important gap refers to the variables in the decision-making process to establish an IBC. In fact, few studies focus on how universities select and value the effects of their different entry modes. Third, this literature review reveals that IBCs have economic effects on the university's home and host countries, but future studies should address the research gaps regarding those effects. Finally, research may also delve into the economic determinants of IBCs in both countries, foreign direct investment, and other variables such as knowledge transfer processes or the effect of an IBC on the development and quality of employment in the host country. All in all, the findings will allow managers and host countries to design the most suitable programs for BCs in order to foster economic development and knowledge transfer from the home countries to the host countries and to meet students' demands.

\section{Acknowledgements}

The authors appreciate the anonymous reviewers' constructive comments. The authors thank professor Rosa Curras Móstoles, Universidad Católica de Valencia (San Vicente Mártir), and Jordi Paniagua, University of Valencia, for their useful comments and suggestions. Send correspondence to María Escriva-Beltran, Faculty of Economics. C/ Corona 34, 46003 Valencia (Spain) Universidad Católica de Valencia (San Vicente Mártir) (maria.escriva@ucv.es); Javier Muñoz-de-Prat, Faculty of Economics. C/ Corona 34, 46003 Valencia (Spain) Escuela de Doctorado de la Universidad Católica de Valencia (San Vicente Mártir) (javier.munoz@ucv.es); Cristina Villó, Escuela de Doctorado de la Universidad Católica de Valencia (San Vicente Mártir). C/ Guillem de Castro, 65, 46008 Valencia (Spain) (cristinavillo@gmail. com).

\section{References}

Ahmad, S. Z., \& Buchanan, F. R. (2016). Choices of destination for transnational higher education: "Pull" factors in an Asia Pacific market. Educational Studies, 42(2), $163-180$.

Altbach, P. G. (2004). Globalisation and the university: Myths and realities in an unequal world. Tertiary Education and Management, 10(1), 3-25.

Altbach, P. G. (2007a). Globalization and the university: Realities in an unequal world. International handbook of higher education (pp. 121-139). Dordrecht: Springer.

Altbach, P. G. (2007b). The imperial tongue: English as the dominating academic language. Economic and Political Weekly, 42(36), 3608-3611.

Altbach, P. G. (2015). Why branch campuses may be unsustainable. International Higher Education, 58. Online at https://ejournals.bc.edu/ojs/index.php/ihe/article/view/ $8467 / 7601$.

Altbach, P. G., \& Knight, J. (2007). The internationalization of higher education: Motivations and realities. Journal of Studies in International Education, 11(3-4), 290-305. 
Bartell, M. (2003). Internationalization of universities: A university culture-based framework. Higher Education, 45(1), 43-70. https://doi.org/10.1023/ A:1021225514599.

Becker, R. F. (2009). International branch campuses: Markets and strategies. Observatory on borderless higher education.

Beecher, B., \& Streitwieser, B. (2017). A risk management approach for the internationalization of higher education. Journal of the Knowledge Economy, 1-23.

Bhanji, Z. (2008). Transnational corporations in education: Filling the governance gap through new social norms and market multilateralism. Globalisation, Societies and Education, 6(1), 55-73.

Bhuian, S. N. (2016). Sustainability of Western branch campuses in the Gulf Region: Students' perspectives of service quality. International Journal of Educational Development, 49, 314-323.

Borgos, J. (2016). Addressing sustainable international branch campus development through an organizational structure lens: A comparative analysis of China, Qatar, and the United Arab Emirates. Chinese Education \& Society, 49(4-5), 271-287.

Cheng, Y. C., Cheung, A. C., \& Yeun, T. W. (2011). Development of a regional education hub: The case of Hong Kong. International Journal of Educational Management, 25(5), 474-493.

Crombie-Borgos, J. (2013). An examination of interconnectedness between U.S. international branch campuses and their host countries. ProQuest LLC.

Crosling, G. (2011). Chapter 6.4 Defining identity, engaging teachers and engaging students: 'education strengths' in a foreign branch campus. Institutional transformation to engage a diverse student body. Vol. 6. Institutional transformation to engage a diverse student body (pp. 245-252). Emerald Group Publishing Limited.

Datta, K. S., \& Vardhan, J. (2017). A SERVQUAL-Based Framework for Assessing Quality of International Branch Campuses in UAE: A Management Students' Perspective. SAGE Open, 7(1) (2158244016676294).

Edwards, R., Crosling, G., \& Lim, N.-C. (2014). Organizational structures for international universities implications for campus autonomy, academic freedom, collegiality, and conflict. Journal of Studies in International Education, 18(2), 180-194.

Eldridge, K., \& Cranston, N. (2009). Managing transnational education: does national culture really matter? Journal of Higher Education Policy and Management, 31(1), 67-79. https://doi.org/10.1080/13600800802559286.

Franklin, A., \& Alzouebi, K. (2014). Sustainability of international branch campuses in the United Arab Emirates: A vision for the future. The Journal of General Education, 63(2-3), 121-137.

Gallagher, S., \& Garrett, G. (2012). From university export to the multinational university: The internationalization of higher education in Australia and the United States. US Study Centre.

Garrett, R. (2017). International branch campuses-Curiosity or important trend. International Higher Education, (90), 7-8.

Garrett, R., Kinser, K., Lane, J. E., \& Merola, R. (2016). International branch campuses: Trends and developments, 2016. London, UK: The Observatory on Borderless Higher Education and C-BERT (Cross-Border Education Team).

Garrett, R., \& Verbik, L. (2004). Transnational delivery by UK higher education, part 1: Data and missing data. London: Observatory on Borderless Higher Education.

Girdzijauskaite, E., \& Radzeviciene, A. (2014). International branch campus: Framework and strategy. Procedia - Social and Behavioral Sciences, 110, 301-308.

Gopal, A. (2011). Internationalization of Higher Education: Preparing Faculty to Teach Cross-Culturally. International Journal of Teaching and Learning in Higher Education, 23(3), 373-381.

Golkowska, K. U. (2016). Negotiating Academic Identity on a North-American Branch Campus. Arab World English Journal, 7(4), 3-12.

Guimon, J. (2016). Universities as multinational enterprises? The multinational university analyzed through the eclectic paradigm. Multinational Business Review, 24(3), 216-228.

Harding, L. M., \& Lammey, R. W. (2011). Operational considerations for opening a branch campus abroad. New Directions for Higher Education, 2011(155), 65-78.

Healey, N. (2014). When is an international branch campus. International Higher Education, (78), 22-23.

Healey, N. (2015a). Managing international branch campuses: What do we know. Higher Education Quarterly, 69(4), 386-409.

Healey, N. (2015b). Towards a risk-based typology for transnational education. Higher Education, 69(1), 1-18.

Healey, N. M. (2016). The Challenges of Leading an International Branch Campus: The "Lived Experience" of In-Country Senior Managers. Journal of Studies in International Education, 20(1), 61-78. https://doi.org/10.1177/1028315315602928.

Healey, N., \& Michael, L. (2015). Towards a new framework for analysing transnational education. Higher Education Policy, 28(3), 369-391.

Healey, N. M., \& Bordogna, C. (2014). From transnational to multinational education: Emerging trends in international higher education. Internationalisation of Higher Education, 3, 33-56.

Hoyt, J., \& Howell, S. (2012). Why students choose the branch campus of a large university. The Journal of Continuing Higher Education, 60(2), 110-116.

Hughes, R. (2011). Strategies for managing and leading an academic staff in multiple countries. New Directions for Higher Education, 2011(155), 19-28.

Jiang, N., \& Carpenter, V. (2011). Market entry dynamic framework for higher education internationalisation. Journal of International Education in Business, 4(2), 141-158.

Jormanainen, I., \& Koveshnikov, A. (2012). International activities of emerging market firms. Management International Review, 52(5), 691-725.

Kehm, B. M., \& Teichler, U. (2007). Research on internationalisation in higher education. Journal of Studies in International Education, 11(3-4), 260-273.

Kinser, K., \& Lane, J. (2015). Foreign outposts of colleges and universities. International Higher Education(66).

Knight, J. (2008). Higher education in turmoil. The changing world of internationalisation.
Rotterdam, The Netherlands: Sense Publishers.

Knight, J. (2011). Education Hubs: A Fad, a Brand, an Innovation? Journal of Studies in International Education, 15(3), 221-240. https://doi.org/10.1177/ 1028315311398046

Knight, J. (2013). International education hubs: Student, talent, knowledge-innovation models. Dordrecht, The Netherlands: Springer Science \& Business Media.

Knight, J. (2014a). Education hubs: Issues, indicators and reflections. In J. Knight (Ed.). International Education Hubs (pp. 207-228). Dordrecht, The Netherlands: Springer.

Knight, J. (2014b). International education hubs: Collaboration for competitiveness and sustainability. New Directions for Higher Education, 2014(168), 83-96.

Knight, J. (2014c). Understanding Education Hubs Within the Context of Crossborder Education. International Education Hubs (pp. 13-27). Dordrecht: Springer. https://doi. org/10.1007/978-94-007-7025-6 2.

Knight, J. (2015). International universities: Misunderstandings and emerging models? Journal of Studies in International Education, 19(2), 107-121 (Retrieved from http:// journals.sagepub.com/doi/abs/10.1177/1028315315572899).

Knight, J., \& Lee, J. (2014). An analytical framework for education hubs. International education hubs (pp. 29-42). Dordrecht, The Netherlands: Springer.

Knight, J., \& Morshidi, S. (2011). The complexities and challenges of regional education hubs: Focus on Malaysia. Higher Education, 62(5), 593.

Kosmützky, A. (2014). Macro-environmental mapping of international branch campus activities of universities worldwide. Research \& Occasional Paper Series: CSHE.2.14Center for Studies in Higher Education. Retrieved from https://eric.ed. gov/?id=ED545192.

Kosmützky, A., \& Putty, R. (2016). Transcending borders and traversing boundaries: A systematic review of the literature on transnational, offshore, cross-border, and borderless higher education. Journal of Studies in International Education, 20(1), 8-33.

Lane, J. E. (2011). Importing private higher education: International branch campuses. Journal of Comparative Policy Analysis: Research and Practice, 13(4), 367-381.

Lane, J. (2013, February). Impact of International Branch Campuses on Science Diplomacy. AAAS Annual Meeting USA, Boston.

Lane, J. E. (2015). Higher education internationalization: Why governments care. New perspectives on internationalization and competitiveness (pp. 17-30). Cham: Springer.

Lane, J., \& Kinser, K. (2011a). Reconsidering privatization in cross-border engagements: The sometimes public nature of private activity. Higher Education Policy, 24(2), $255-273$.

Lane, J., \& Kinser, K. (2011b). Multinational colleges and universities: Leading, governing, and managing international branch campuses. New directions for higher education, number 155. John Wiley \& Sons.

Lane, J., \& Kinser, K. (2013). Five models of international branch campus ownership. International Higher Education, (70), 9-11.

Lawton, W., \& Katsomitros, A. (2012). International branch campuses: Data and developments. The Observatory on Borderless Higher Education.

Lee, J. T. (2015). Soft power and cultural diplomacy: Emerging education hubs in Asia. Comparative Education, 51(3), 353-374.

Lim, A. H., \& Saner, R. (2011). Trade in Education Services: Market Opportunities and Risks (SSRN Scholarly Paper No. ID 1807291). Rochester, NY: Social Science Research Network. Retrieved from https://papers.ssrn.com/abstract $=1807291$.

Macdonald, I. (2006, July). Offshore university campuses: Bonus or baggage. 29th HERDSA Annual Conference (pp. 207-215).

Marginson, S., \& van der Wende, M. (2007). Globalisation and Higher Education. OECD Education Working Papers, No. 8. OECD Publishing.

Mazzarol, T., Norman Soutar, G., \& Sim Yaw Seng, M. (2003). The third wave: Future trends in international education. International Journal of Educational Management 17(3), 90-99.

McBurnie, G., \& Pollock, A. (2000). Opportunity and Risk in Transnational Education-Issues in Planning for International Campus Development: An Australian Perspective. Higher Education in Europe, 25(3), 333-343. https://doi.org/10.1080/ 713669272.

McBurnie, G., \& Ziguras, C. (2006). Transnational education: Issues and trends in offshore higher education. Routledge.

McBurnie, G., \& Ziguras, C. (2009). Trends and future scenarios in programme and institution mobility across borders. Globalisation: . Vol. 2. Higher Education to 2030 (pp. 89-108). Paris: OECD Publishing. Retrieved from http://www.oecd-ilibrary.org/ content/chapter/9789264075375-5-en.

Middlehurst, R., \& Woodfield, S. (2007). Responding to the internationalisation agenda: implications for institutional strategy. Retrieved from http://eprints.kingston.ac.uk/ $1720 /$.

Naidoo, V. (2006). International education: A tertiary-level industry update. Journal of Research in International Education, 5(3), 323-345.

Naidoo, V. (2009). Transnational higher education: A stock take of current activity. Journal of Studies in International Education, 13(3), 310-330.

Nguyen, P. M., Elliott, J. G., Terlouw, C., \& Pilot, A. (2009). Neocolonialism in education: Cooperative learning in an Asian context. Comparative Education, 45(1), 109-130.

OBHE/C-BERT (2016). International branch campuses: Trends and developments. London: The Observatory on Borderless Higher Education/Cross-Border Education Research Team.

Phillips, N., Tracey, P., \& Karra, N. (2009). Rethinking institutional distance: strengthening the tie between new institutional theory and international management. Strategic Organization, 7(3), 339-348. https://doi.org/10.1177/1476127009337439.

Schuman, S. (2009). "Put Money in Thy Purse": Fund-Raising at Public Branch Campuses. In Barton, S. J., Berger, A. H., Book, P. A., Dengerink, H. A., Epstein, M., Heaphy, L., .. \& Malnarich, G. (Eds.). Leading America's branch campuses (pp. 245-260). R\&L Education

Salt, J., \& Wood, P. (2014). Staffing UK university campuses overseas: Lessons from MNE practice. Journal of Studies in International Education, 18(1), 84-97. 
Shams, F., \& Huisman, J. (2012). Managing offshore branch campuses: An analytical framework for institutional strategies. Journal of Studies in International Education, 16(2), 106-127.

Shams, F., \& Huisman, J. (2014). The role of institutional dual embeddedness in the strategic local adaptation of international branch campuses: Evidence from Malaysia and Singapore.

Shams, F., \& Huisman, J. (2016). The role of institutional dual embeddedness in the strategic local adaptation of international branch campuses: Evidence from Malaysia and Singapore. Studies in Higher Education, 41(6), 955-970.

Sia, E. (2015). Student motivation, intercultural competence and transnational higher education: Uzbekistan, a case study. Journal of the Scholarship of Teaching and Learning, 15(1), 57-69. Retrieved from https://eric.ed.gov/?q = \%22transnational + education $\% 22+$ AND $+\% 22$ international + Branch + Campus $\% 22 \&$ id $=$ EJ1052563.

Singh, G. (2014). Understanding determinants for service FDI: The case of education service providers (Ph.D. thesis) Retrieved from http://researchdirect.westernsydney. edu.au/islandora/object/uws\%3A32322/.

Smith, L. (2009). Sinking in the sand? Academic work in an offshore campus of an Australian university. Higher Education Research and Development, 28(5), 467-479.

Spring, J. (2009). Globalization of education: An introduction (sociocultural, political, and historical studies in education). New York: Routledge.

Surdu, I., \& Mellahi, K. (2016). Theoretical foundations of equity based foreign market entry decisions: A review of the literature and recommendations for future research. International Business Review, 25(5), 1169-1184.

Tierney, W. G., \& Lanford, M. (2015). An investigation of the impact of international branch campuses on organizational culture. Higher Education, 70(2), 283-298. https://doi.org/10.1007/s10734-014-9845-7.

van Rooijen, M. (2006). The future of multinational universities. In M. Kelo (Ed.). The Future of the University. Bonn, Germany: Lemmens.

Verbik, L. (2015). The international branch campus: Models and trends. International Higher Education(46).

Verbik, L., \& Merkley, C. (2006). The international branch campus-Models and trends. Redhill: Observatory on Borderless Higher Education.

Wallace, M., \& Dunn, L. (2013). Teaching in transnational higher education: enhancing learning for offshore international students. New York, The U.S.A.: Routledge.

Waterval, D. G. J., Frambach, J. M., Driessen, E. W., \& Scherpbier, A. J. J. A. (2015). Copy but not paste: A literature review of crossborder curriculum partnerships. Journal of Studies in International Education, 19(1), 65-85.

Wilkins, S. (2010). Higher education in the United Arab Emirates: An analysis of the outcomes of significant increases in supply and competition. Journal of Higher Education Policy and Management, 32(4), 389-400.

Wilkins, S. (2011). Who benefits from foreign universities in the Arab Gulf States? The Australian Universities' Review, 53(1), 73-83.

Wilkins, S. (2012). The future of transnational higher education: What role for international branch campuses? In H. de Wit, F. Hunter, L. Johnson, \& H. van Liempd (Eds.). Possible futures: The next 25 years of the internationalisation of higher education (pp. 182-186). Amsterdam: European Association for International Education.

Wilkins, S. (2013). The future of transnational higher education: What role for international branch campuses? Possible Futures: The Next 25 Years of the Internationalisation of Higher Education (pp. 182-186). .

Wilkins, S. (2016). Establishing international branch campuses: A framework for assessing opportunities and risks. Journal of Higher Education Policy and Management, 38(2), 167-182.

Wilkins, S. (2017). Ethical issues in transnational higher education: The case of international branch campuses. Studies in Higher Education, 42(8), 1385-1400.

Wilkins, S., \& Balakrishnan, M. (2012). Student Perception of Study at International Branch Campuses: Implication for Educators and College Managers. In V. Huang, M. Balakrishnan, \& I. Moonesar (Eds.). Conference Proceedings and Program: Academy of International Business - Middle East North Africa Chapter 2nd Annual International Conference (pp. 61). Dubai: Academy of International Business- Middle East North Africa Chapter (AIB-MENA).

Wilkins, S., \& Balakrishnan, M. S. (2013). Assessing student satisfaction in transnational higher education. International Journal of Educational Management, 27(2), 143-156.

Wilkins, S., Balakrishnan, M. S., \& Huisman, J. (2012). Student choice in higher education: Motivations for choosing to study at an international branch campus. Journal of Studies in International Education, 16(5), 413-433.

Wilkins, S., \& Huisman, J. (2012). The international branch campus as transnational strategy in higher education. Higher Education, 64(5), 627-645.

Wilkins, S., \& Huisman, J. (2013). Student evaluation of university image attractiveness and its impact on student attachment to international branch campuses. Journal of Studies in International Education, 17(5), 607-623.

Wilkins, S., \& Huisman, J. (2014). Corporate images' impact on consumers' product choices: The case of multinational foreign subsidiaries. Journal of Business Research, 67(10), 2224-2230.

Wilkins, S., \& Huisman, J. (2015). Factors affecting university image formation among prospective higher education students: The case of international branch campuses. Studies in Higher Education, 40(7), 1256-1272.

Wilkins, S., \& Urbanovic, J. (2014). English as the lingua franca in transnational higher education: Motives and prospects of institutions that teach in languages other than English. Journal of Studies in International Education, 18(5), 405-425.

Zhang, L., Kinser, K., \& Shi, Y. (2014). World economies and the distribution of international branch campuses. International Higher Education, 77, 8-9.

Ziguras, C. (2013). The cultural politics of transnational education: Ideological and pedagogical issues for teaching staff. In L. Dunn, \& M. Wallace (Eds.). Teaching in transnational education: Enhancing learning for offshore international students (pp. 4454). London, UK: Routledge. 